Vol. 8, nº 1 | 2004

Varia

\title{
Fulfilling Their Mission: The Intervention of Voluntary Societies in Cases of Sexual Assault in the Victorian Criminal Process
}

\section{Kim Stevenson}

\author{
(2) OpenEdition \\ Journals \\ Electronic version \\ URL: https://journals.openedition.org/chs/519 \\ DOI: $10.4000 /$ chs. 519 \\ ISSN: 1663-4837 \\ Publisher \\ Librairie Droz

\section{Printed version} \\ Date of publication: 1 August 2004 \\ Number of pages: $93-110$ \\ ISBN: 2-600-00955-8 \\ ISSN: 1422-0857
}

\section{Electronic reference}

Kim Stevenson, "Fulfilling Their Mission: The Intervention of Voluntary Societies in Cases of Sexual Assault in the Victorian Criminal Process", Crime, Histoire \& Sociétés / Crime, History \& Societies [Online], Vol. 8, $n^{\circ} 1$ | 2004, Online since 25 February 2009, connection on 24 March 2022. URL: http:// journals.openedition.org/chs/519; DOI: https://doi.org/10.4000/chs.519

This text was automatically generated on 24 March 2022.

(C) Droz 


\title{
Fulfilling Their Mission: The Intervention of Voluntary Societies in Cases of Sexual Assault in the Victorian Criminal Process
}

\author{
Kim Stevenson
}

\section{AUTHOR'S NOTE}

The author wishes to express her thanks to the reviewers for their comments and suggestions.

1 Much has been written on the role of nineteenth century voluntary societies and philanthropic organizations in seeking to achieve social purity and moral reform through 'rescue' work and evangelical dogma ${ }^{3}$. The early campaigns of the Vice Society targeting vice and obscenity, paranoia about prostitution in the $1840 \mathrm{~s}$ and $50 \mathrm{~s}$, and anxieties about saving the souls of women and girls involved in immoral activities, led to a flood of evangelically inspired institutions formed to gather up and save such fallen females. In the 1870s and 80s, the unwavering commitment and influence of

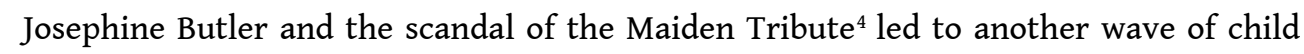
saving initiatives, and the formation, ultimately, of the National Vigilance Association. But, apart from the Vice Society's prosecutions of those running brothels and selling obscene material, and Butler's disillusion with the National Vigilance Association, what has been less well publicized by academic commentators and modern historians, is the contribution many of these philanthropic societies made to the practical operation of the criminal justice system. A number of these societies, both local and national, were actively engaged in initiating prosecutions, representing defendants and developing agendas that included legal support and assistance for those perceived to be the most vulnerable in society, women and children. Lacking economic resources, and denied both political and legal power in any substantial sense, women and children were, for 
the Victorians, the most obvious and least protected participants in the legal process. As victims, they were also among the most deserving, especially in cases of sexual assault and violence. But the societies did not just confine themselves to cases where women and children were victims, they also intervened where women and young girls were charged as defendants, whether for minor crimes such as theft and pilfering or more serious crimes such as husband murder ${ }^{5}$. As a result more and more women and children came to the attention of the ever-increasing number of societies. Contemporaries recognized the part played by these societies in protecting such individuals and representing their interests through the provision of advice, lay and legal representation, and financial support, as something making a significant contribution to the effective workings of the legal system and its ability to deliver 'justice.'

2 The aim of this paper is to start to bring to light the importance of the role played by a number of these societies in actively engaging with, and proactively intervening in, the criminal justice system. In the context of Victorian child sexual abuse, Louise Jackson has already identified and highlighted the importance of the involvement of charitable organizations in such cases ${ }^{6}$. But with regards to rape there has been less methodical introspection ${ }^{7}$. However, a caveat must be entered first in terms of the difficulties of conducting any systematic research into the activities of these societies, as few records are readily available in convenient sources. As Prochaska found when researching his leading text, Women and Philanthropy in Nineteenth Century England, for most of the thousands of charitable institutions that then existed, records are scant and long runs of annual reports rare ${ }^{8}$. The major source used has therefore been newspaper reports of court cases heard at the police courts and assizes where a society is cited as instigating a prosecution, supporting a complainant or representing an accused. Such information has been extrapolated from an ongoing and qualitative survey of the daily digests of reported cases of crime and misdemeanors from a range of Victorian newspapers selected at five yearly intervals between 1850 and $1885^{\circ}$. Even so this is far from comprehensive as in many cases newspaper reports fail to mention or identify any organization involved. Often their participation appears to be implicit only, with a familiar name, usually the secretary or prosecuting officer, indicating the interests of a particular society.

3 This research has though, been able to exploit, for the first time, the records of the Associated Societies for the Protection of Women and Children, formerly the Society for the Protection of Women and Children (hereinafter referred to as the ASPWC, and pre-1878 the SPWC), held in the Rainer Foundation Archive ${ }^{10}$. Another difficulty in sourcing material is that many Victorian philanthropic societies regularly merged or mutated necessitating a change of name. Initially calling themselves a society when operating within a locality, such organizations preferred the title institute, or association, when taking on a national identity. The Society for the Protection of Women and Children was established in 1857 but became a national organization - the Associated Societies for the Protection of Women and Children under the chairmanship of the Marquis of Townsend in $1878^{11}$. To add further confusion, the names of many of the societies that worked with women and children are very similar so although they are identified as separate organizations it is possible that certain of them could be one and the same. The main societies selected for this research, either because they feature most prominently in press reports or their records are contained in the Rainer Archive, 
are: the Associate Institution for Improving and Enforcing the Laws for the Protection of Women - founded in 1843 and still operating in 1872; the Associate Institute for the Protection of Females, formerly the Society for the Protection of Young Women, founded in 1844 by Henry Phillips, Bishop of Exeter ${ }^{12}$; and the Associated Societies for the Protection of Women and Children 1857 to 1919 or ASPWC ${ }^{13}$.

\section{Eighteenth Century Origins}

4 In order to understand the significance of the role of these organizations some consideration of their location within the broader context of Victorian philanthropic and charitable practice, itself heavily influenced by the charitable initiatives of the eighteenth century, is informative. Victorian philanthropic societies tended to divide into one of two models that developed and became established during the eighteenth century, those that espoused an overt moral agenda and those that acted as prosecuting societies.

5 The former developed from the rise of evangelicalism in the latter half of the century and the belief that the success of the nation state relied upon universal material improvement, something that could only be achieved by significant moral regeneration, greater self-dependency and the improvement of manners ${ }^{14}$. Thus eighteenth century philanthropists, many embracing utilitarian principles, spawned a national movement operated through numbers of organizations, both regulatory and charitable, to eliminate 'evil' and ensure that all individuals, whatever their circumstances, contributed something positive to the community. As Hitchcock concludes, the role of these moral societies was primarily «to impose order on society rather than seeking to transform any one individual $»^{15}$. Andrew asserts that charity therefore ceased to be a hobby and became a «serious scientific avocation» ${ }^{16}$. She identifies three forms of engagement that these moral improvement societies provided for women ${ }^{17}$. Maternal charities, including hospitals such as the Foundling, provided mothers with practical support at birth and with raising their young families. Formed to encourage population growth because of demographic shifts to the colonies, the status of these charities waned as the resources consumed by the multiplying laboring poor and their increasing dependency on the state were not matched by their economic contribution. Consequently, from the 1770s onwards, while many of these maternal and Lying-in charities tried to keep pace with delivery rates, financial difficulties and changes in public attitudes heralded their decline. Secondly, concerns about poor parenting and a belief that the social order depended on mutual self-interest led to the founding of the Philanthropic Society in 1788. This society aimed to re-educate idle and immoral parents by 'rescuing' their children and providing them with proper education and vocational training as an alternative to the workhouse. Children would only be returned to their families once their parents had made the transition to respectability. Thus the charity provided a form of indirect, if emotionally brutal, support for women by taking over their childcare responsibilities. Thirdly, eighteenth century philanthropy towards women, especially at the close of the century, started to focus heavily on distinguishing the good from the bad, the pure from the impure. The perceived dangers to society posited by female prostitution and vice necessitated and justified the physical separation of one from the other. Societies, such as those for the Reformation of Manners, embraced this moral and political agenda and sought to 
persecute and prosecute prostitutes as a means of disciplining and punishing them ${ }^{18}$. Others, such as the Magdalen Hospital for Penitent Prostitutes, adopted less punitory means providing refuge accommodation for 'fallen' women in return for their labour laundering, and their commitment to moral reform.

The second type of philanthropic model inherited from the eighteenth century constituted numbers of local societies, often trade associations, which acted as 'prosecution societies.' Without the establishment, at least until 1829 onwards, of an effective and organized police force there was no official body responsible for initiating criminal prosecutions ${ }^{19}$. Victims of, primarily, theft and deceit, were therefore obliged to seek justice by bringing private prosecutions, potentially a costly measure ${ }^{20}$. Hundreds of voluntary associations, funded by individual subscriptions, offered financial support and the recruitment of legal professionals to assist their members in pursuing legal cases $^{21}$. In particular, some 450 Associations for the Prosecution of Felons offered a form of early legal aid and assistance encompassing the detection and apprehension of offenders and their subsequent prosecution at the Magistrates Court, Quarter-Sessions or Assizes ${ }^{22}$. These associations were particularly active between 1780-1850, largely in line with the simultaneous expansion of summary justice began in the eighteenth century and culminating in the major reforms of the $1820 \mathrm{~s}$ and $1850 \mathrm{~s}$ with the realization that the sanctity of trial by jury could no longer apply universally ${ }^{23}$. Another factor was the increasing involvement of lawyers within that process necessitating the provision of equal representation for ordinary citizens ${ }^{24}$. At the turn of the century a considerable number of summary offences existed and after 1840 these grew rapidly ${ }^{25}$ as the legislature recognized the advantages of a more codified and formalized criminal law. Procedural reforms in the 1820s permitted the delegation of jurisdiction for summary offences from the Quarter Sessions to the Petty Sessions and also allowed payment for expenses incurred in bringing cases ${ }^{26}$. The Police Courts' Act 1839 created the first nine police courts with summary jurisdiction and further developments followed in the 1850s increasing the role and powers of the magistrates and police courts, including the use of committal proceedings in these summary courts $^{27}$. The Associations for the Prosecution of Felons attempted to keep pace with these reforms and offered a service to those unable or unwilling to personally undertake private prosecutions or engage the official law-enforcement agencies. However, this service did not extend to female victims of violence, especially sexual violence. Caseloads tended to focus on property crime and membership was restricted to (less propertied) men. Some associations did admit women but these were primarily widows who needed to protect their property interests ${ }^{28}$.

7 Women who found themselves raped or assaulted fell between these two models. Prosecuting societies rarely prosecuted cases of violence and moral societies were more concerned with eliminating immoral behavior than supporting the recipients of it. Sexual violence received less attention than property crime and, in the domestic sphere at least, cases often only came to light where they were incidental to matrimonial or bastardy proceedings ${ }^{29}$. In the public sphere, few men of status were convicted of rape and child sexual abuse was a phenomenon that was not even properly publicly acknowledged $^{30}$. Many complaints of rape or attempted rape were either dismissed before reaching trial or the male triumvirate of judges, jurors and counsel ensured that acquittals were all too common ${ }^{31}$. As Carolyn Conley confirms, «it was difficult for the males who ran the criminal justice system to fully comprehend the criminality of rape $»^{32}$. Criminal proceedings for sexual assault required instigation by the victim or 
her family, but victimised women risked tarnishing their reputation by making a formal complaint. Women who brought rape charges were suspect on three counts, they were female, had been at least temporarily outside the supervision of their male protector and were publicly announcing their loss of sexual innocence ${ }^{33}$. Often such cases were settled out of court and judges would routinely dismiss cases where the victim's protector had accepted compensation ${ }^{34}$. Such informal resolution was popular as not only were there considerable evidential difficulties in bringing such cases to trial but there were practical difficulties too. For less serious assaults, the summary jurisdiction of the magistrates did not normally incur any financial obligation, but the higher courts, except for charges of rape, required the injured person to bear the financial costs of the prosecution at least until conviction when some reparation might be available.

\section{Tentative Beginnings}

8 Organized or 'associated' philanthropy continued to proliferate in the nineteenth century. As the powers and role of the state expanded so too did the voluntary sector ${ }^{35}$. In addition, as Prochaska highlights, organized philanthropy became 'womanized ${ }^{36}$.' There was an explosion not only in the number of societies run by women and which involved women, but also as many societies brought child welfare and moral reform to the fore, so too did they exert a profound effect and impact on women's lives and expectation $s^{37}$. As the nineteenth century progressed, societal expectations and norms of what constituted acceptable behaviour for both men and women hardened. As Wiener argues, this involved a «civilizing» process, enforced by the increasing intervention of the criminal law and legal system, which aimed to redefine the ideal attributes of masculinity and femininity. For women this meant the preservation of their moral and sexual integrity, for men it meant controlling any aggressive or violent disposition ${ }^{38}$. Thus from the 1850 s onwards a number of prosecution societies emerged that aimed to use the law as best they could to protect women and children from violence, immorality and vice. Their activities indicate the extent to which the Victorians held a real belief that the moral state of women was central to the good health and security of the nation. While many of these societies promoted a strong moral agenda they successfully bridged the two disparate eighteenth century models by undertaking a considerable amount of legal work in relation to cases involving women and children. For a variety of reasons including cost, this was mostly at the summary level. Together with the fact that many of their records have proved so elusive this might explain why the significance of these societies has been largely overlooked by historians. The more prominent of these societies, certainly in terms of their representation of feminine interests, tend to be best known now for their rescue activities in saving the 'imperfect' or fallen woman ${ }^{39}$, or for their lobbying and sponsorship of various legal provisions, particularly in the 1840s and 1880s in respect of the problems of child prostitution and defilement ${ }^{40}$. As Louise Jackson confirms in her seminal work on Victorian child sexual abuse, histories of the child protection movement have tended to focus more on the work of the NSPCC, which in any case was not founded until 1884 whereas many of these societies were active much earlier ${ }^{41}$. In fact it would appear that the organization and activities of these societies may have provided an early model for the NSPCC. Similarly much has been written on the 
philanthropic work of Josephine Butler and Ellice Hopkins but their influences too came much later.

9 From the 1850s then a proliferation of reported cases of sexual assault where the prosecution was sponsored by a rescue society or philanthropic organization start to appear. Jackson notes that throughout the 1860s, 1870s and early 1880s, the Associate Institute for the Protection of Women and Children, was actively involved in the prosecution of at least 34 cases at the Old Bailey and Middlesex Quarter Sessions of the 200 odd cases she surveyed ${ }^{42}$. But at least four different prosecutory societies were already operating within the jurisdiction of the Middlesex Quarter Sessions in the 1850s, the main London court for serious crimes. These included the Society for the Rescue of Young Women and Children; Institution for Improving and Enforcing the Laws for the Protection of Women; Associate Institute for the Protection of Females, and the Vice Society. Though there is a reference in The Times to the successful prosecution by the Society for the Rescue of Young Women and Children against Soloman Hyams for indecently assaulting Catherine Samuels, aged 11 years, in 1856, it is the Associate Institution for Improving and Enforcing the Laws for the Protection of Women that appears more frequently ${ }^{43}$. Also a rescue society, this body was initially concerned with the procurement into brothels of young girls. However, Edward Bristow asserts that despite some strong support from the bishops and the anti-slavery movement it largely «fell flat on its face» ${ }^{44}$. It is certainly true that the institution struggled to establish its credentials within the legal arena and initially failed to find favour with the judiciary as indicated in 1852 when it instructed Mr. Lawrence to prosecute the case of Mary Burch, aged 12 years. Mary had complained to her mother that Charles Tillotson, a respectable married man, had "pulled her about indecently» in the hairdressers where he was working. Defence counsel claimed she must have «misunderstood his intentions» as «he was only playing with her». The judge at the Middlesex Sessions, Serjeant Adams, acquitted Tillotson, and criticised the Institute for getting involved in the case and refused to allow any expenses «for he had no idea of them thrusting themselves forward in this way» ${ }^{45}$.

Notwithstanding such an ignominious start, and contrary to Bristow's criticism, the institution quickly became very active in the 1850s and genuinely attempted to live up to its name taking on cases, that today, would be regarded as difficult in the extreme. In 1857, for example, proceedings were instigated by the Institute at the Central Criminal Court against Jacob Israel for indecently assaulting an 18 year-old «idiot». The legal complexities of introducing plaintiffs suffering from a mental disability into court are illustrated by the fact that Justice Willes found it necessary to remove her immediately as she was neither «capable of exercising her will in any description [and] was totally unaware of the object of his violence or what had happened». As any absence of consent was not clear Israel was found not guilty but it is significant that the institution was at least willing to attempt to bring such a case ${ }^{46}$. In 1858 , the Institute enjoyed some major successes before Justice Creasey at Middlesex Assizes suggesting he was more willing to acknowledge their role and efforts than Serjeant Adams. Hugh Baker, the chief mate of a merchant vessel, charged with indecently assaulting Ann Brooks, aged 21 years, with intent, was found guilty, albeit of the lesser, and easier to prove, charge of common assault ${ }^{47}$. Three young men were also convicted for indecently assaulting young girls. Patrick Sarsfield, aged 22 years, was sentenced to two years hard labour for indecently assaulting Ellen Crook, a child under the age of $10^{48}$, and Noah Canlet also 22 
years, whom Creasey ordered to «Go away nasty beast. You are a disgrace», was imprisoned for one year with hard labour for indecent assaulting 11 year-old Ellen Ball ${ }^{49}$. The third which, without a confession, might well remain on the prosecutor's desk today, was that of George James, 20 years, charged with indecent assault and sentenced to two years imprisonment. According to The Times this «atrocious assault with the most distressing consequences» was perpetrated upon Elizabeth Jane Brown, the sister of the woman he cohabited with - Elizabeth was just 2 years old ${ }^{50}$. Given that many cases of sexual assault on young children failed due to a lack of convincing evidence $^{51}$ this must have been quite an achievement and the Institute continued to lead a significant number of prosecutions well into the 1870 s.

11 Though the Institution for Improving and Enforcing the Laws for the Protection of Women has been much maligned both by modern and, in its early founding years, contemporary critics, 20 years after Sergeant Adams, at the Middlesex sessions, seemingly dismissed its operation, the picture changed considerably. In March 1870 after Mr. Besley, for the Institute, successfully prosecuted Thomas Austin for indecently assaulting his own illegitimate daughter, Alicia Amelia Holloway, aged under 10 years, the judge at Middlesex Assizes publicly stated that, «the society by whom the prosecution had been conducted were most beneficial in such cases, and very properly took them up where the parties themselves, from their poverty, were unable to employ counsel to lay the facts before the court; and but for them many cases might not be prosecuted at all, or if prosecuted, the facts would not be properly laid before the jury» ${ }^{52}$.

\section{A Legal Consciousness}

The legal work undertaken by these societies extended well beyond the prosecution of actual cases of physical and sexual assault. The Rainer Archive reveals that the Associated Societies for the Protection of Women and Children, ASPWC, offered legal advice and assistance in cases of bigamy, seduction, abduction, neglect, and desertion as well as cruelty and sexual assaults. The Society's extensive case load, which covered both aspects of civil and criminal law ${ }^{53}$, included the making of applications to the courts for separation and affiliation orders, finding accommodation for the homeless, assisting in cases of defamation, compensation, protection and property disputes, and even on occasion mediating with foreign consulates where necessary in the interests of the women they represented. Occasional reconciliations were secured as well as weekly payments, varying in 1878 from 4-12 shillings, for deserted wives and illegitimate children from husbands and putative fathers ${ }^{54}$. Applications for advice and pleas for investigation came from a variety of sources including clergymen, police officers, lady correspondents and private individuals. The ASPWC regularly advertised their services in newspapers and journals seeking subscriptions and on occasion directly approached and targeted specific communities. For example, in February 1879, the Society's solicitor, Mr. Caldwell, successfully prosecuted John Crompton, a miller, for assaulting Elizabeth Howard, aged 9 years, and Jean Simmons, 11 years. Crompton received 12 months with hard labour but as he had been so prolific in indecently assaulting young girls in Tendering, Essex, the Society's Council saw an opportunity to replenish their funds ${ }^{55}$. Reverend O'Neill, seconded by Reverend Wickson, instructed Mr. Hardy, their financial secretary and collector, to go to the area to solicit subscriptions «on account 
of the deep interest felt in this case in the neighbourhood of Tendering». Hardy was encouraged in his endeavours by the promise of a $30 \%$ dividend on all contributions he secured and $£ 3$ expenses in addition ${ }^{56}$. The Minute Books are silent as to the success of this campaign but do refer to Hardy being dismissed, over allegations of financial irregularity, and later reinstated. The potential for corruption is self-evident. Hardy's salary was proportionate to the subscriptions he secured $-20 \%$ on the first $£ 400$ of sums obtained per annum, 25\% for sums over that amount, but if he secured less than $£ 250$ his contract would be terminated. He was also required to cover his own expenses. In November Hardy asked for permission to advertise for subscriptions in Croydon and Richmond as a result of successful prosecutions in those localities but the Council, still somewhat suspicious, refused ${ }^{57}$.

Unfortunately press reports of the assizes and police courts do not always stipulate, whether it was the victim, a member of her family, officials from a particular society, or solicitor or legal professional instructed by that society, who were actually responsible for prosecuting a particular case. Generally, as far as the ASPWC is concerned, it appears that where a case was complex or sufficiently serious a solicitor would be instructed, if it were more straightforward, the officers themselves would often prosecute. Mr. Besley, for example, was one such experienced officer who worked for both the Institution for Improving and Enforcing the Laws for the Protection of Women in the early 1870s and then the Vice Society in 1875. In fact sometimes just the mere presence of an officer of a society during a particular court hearing was reported in the newspaper case report. Both the ASPWC and Associate Institute for the Protection of Women ${ }^{58}$ employed a prosecuting officer, who, in addition to actually prosecuting individual cases in court, regularly attended the police courts and petty sessions in a more proactive role in order to assess cases, and offer assistance and support to unrepresented and deserving women and children. The fact that the names of attending officers are sometimes mentioned in press reports suggests that in itself such attendance was not insignificant and that the presence of a prosecuting officer meant that the charge was of a grave nature. An early example from Reynolds Weekly cites the attendance at Bow Street police court of Mr. Henry Allen who «attended to watch on behalf of the Associate Institute for the Protection of Women» though given that «Long before the hour set down for the examination of the witnesses, a large number of persons assembled in the lobbies of the court with a desire to catch a glimpse of the parties as they entered the police court,» it is not altogether clear whether his intentions were of curiosity or charity. The case was, according to the newspaper headline, an unusual one of "A Negro Charged with Rape»"

Prosecuting officers were also engaged on fact-finding missions or to gain information to help in the promotional work of their particular society. The Minute Books of the ASPWC, for example, note that in July 1879, Mr. Stuart, their prosecuting officer, attended court 14 times that month ${ }^{60}$. Mr. Moore of the Associate Institute for the Protection of Women was also a particularly regular attender. One example in the Daily Telegraph court reports in July 1870 confirms his presence at Lambeth Police Court where Dennis Mahoney was charged with kicking his wife to death ${ }^{61}$. However, at the Guilford Assizes, Mahoney's charge was reduced to one of assault despite the fact it took his wife three days to die from lockjaw supervening from her injuries. It is apparent that by including a reference to Moore's attendance at the police court the Daily Telegraph was impressing upon its readers the seriousness of the case affirmed in a 
highly critical editorial of the judge who, «after stating that the unprovoked violence of the prisoner was such as to require a sentence of some severity, pronounced the 'severe' sentence of - eight months hard labour. We are not surprised that notice has been drawn in the newspapers to the singular leniency of this sentence, which even the Judge could not admit to be warranted by any extenuating circumstances» ${ }^{62}$.

The decision to sponsor a case was usually decided by the Society's Council on advice from both their in-house solicitor ${ }^{63}$ and the prosecuting officer. Witnesses were sometimes requested to attend these meetings and evidence might be sought from them in the form of both witness statements and photographic evidence. For example, in June 1879 in a case referred by the Reverend Baker of Woolwich, the Chairman of the ASPWC «very carefully examined Rose McGrath,» 6 years, to see if she was capable of giving evidence in a court of justice against her father who had indecently assaulted her, and her two younger sisters aged 4 and 3. The Minute Books record that she «gave the story of the most disgusting case with much clearness and simplicity of statement» prompting the Council to agree to sponsor the case ${ }^{64}$. Therefore, through practical experience of real life trials the ASPWC found their way through the legal labyrinth and gradually came to realise the importance of securing corroborating evidence wherever possible. Thus complainants of sexual assault, as for example in the case of Kate Howard who alleged her former master had raped her, were often directed by the Society to see a medical examiner before any proceedings were instigated ${ }^{65}$.

Not every application made to the ASPWC received legal funding to support a prosecution, many cases were declined and, less frequently, passed on to the Director of Public Prosecutions once that position was established in $1879^{66}$. Many applicants did not wish for a summons to be issued preferring the matter to be negotiated on their behalf rather than formal proceedings initiated, thus the ASPWC became an early mediator and frequently imposed financial terms on the other party as a means of disposal. In making their decisions, issues of class, race and religious denomination were indeterminate as indicated by the prosecution, conducted by the SPWC (as it was then), of the Earl of Norbury at Sevenoaks Magistrates in 1865. According to the Pall Mall Gazette the noble lord was convicted by the justices and fined $£ 5$ for a common assault - which was in fact a downgraded sexual assault, perpetrated upon a 14 year old maidservant in his Lordship's employ ${ }^{67}$. Conley also refers to the case as reported in the local newspaper, the Tonbridge Telegraph, which notes that Lord Norbury had offered to pay the girl's parents a sum of money to drop the charges ${ }^{68}$. It would appear that they refused and sought the assistance of the Society to initiate a prosecution. The SPWC must have considered it to be a relatively strong case and informal mediation inappropriate as it is unlikely that they would have agreed to prosecute otherwise. Nor was it only where servants were the complainants that the Society involved itself. The Minute Books for 1878 record an incident where the ASPWC represented Sarah Ann Willets, a female servant, charged with the theft of a pocket-handkerchief and two scarves from her employer that had allegedly been planted on her as a result of an apparently genuine allegation of sexual assault she had made against her mistress's son five days before ${ }^{69}$. Thus the society was not unwilling to take on cases involving figures of authority, which, given the respectability code operating at the time, meant that women who found themselves at a huge disadvantage because their alleged assailant was their employer or a police officer, minister, doctor or even lawyer, might receive some support. 
17 Not only did societies sponsor potentially difficult and possibly unpopular applications, they also adopted a proactive stance in challenging perceived injustices where, for example, defendants had been acquitted by lobbying for the re-opening of such cases, though not always successfully. In 1859 Henry Rudlege appeared for the second time at the Central Criminal Court charged with the rape of Ellen Saltmarsh, aged 40 years. The Associate Institute had successfully instigated new proceedings for the Protection of Females after the prisoner had already been tried and acquitted at the previous sessions - presumably because of an erroneous indictment. On this occasion, however, the Institute failed to offer any new prosecution evidence and unsurprisingly he was therefore acquitted again. But it is interesting that the institution was at least prepared to try to re-open the case and its members were obviously of the opinion that justice had not been done $\mathrm{e}^{70}$. In October 1880 the Vigilance Association ${ }^{71}$ forced the re-opening of a case where two 15 year-old girls, on their way home from Sunday evening service, had been attacked by two lads with, according to the Association's publication The Sentinel, «a mature ferocity». The Association intervened because it was concerned that at their trial the defendants' confession of guilt had been dismissed and as a result they had been acquitted ${ }^{72}$. Conversely, the Associate Institution for Improving and Enforcing the Laws for the Protection of Women, secured the committal, at Clerkenwell Police Court, of John Madden and two others for a criminal assault perpetrated on Kitty Earley, aged 15 years. In hearing the Institute's application, «the details of which were unfit for publication but of the most startling character,» according to the newspaper report, the court noted that Kitty's evidence was given with great propriety and supported by independent testimony confirming the 'professionalism' of many of these societies $^{73}$. As their legal experience and knowledge increased so too did the ability of these societies to not only manipulate the legal system but use it to their own advantage, this meant that they were able to instigate and develop their own internal policies and apply and implement their own forms of justice in dealing with the referrals presented to them.

\section{Making their Mark}

18 As Prochaska has convincingly portrayed, philanthropy was primarily a female occupation in terms of the numbers involved, and the mid-Victorian period was the "heyday of female charitable activity» ${ }^{74}$. In the 1850 s it is estimated that there were over 400 philanthropic societies ${ }^{75}$, by the 1880 s there were thousands and over 500,000 women were involved in philanthropic work together with a further 20,000 paid officials, mainly district officers and collectors ${ }^{76}$. Crucially, and again this is something that has not really been considered, the prosecutory role of these societies permitted women to become involved in the predominantly male legal process in ways they had not been able to before. This provided an opportunity for (middle-class) women not only to do something useful but also to take on a patriotic role in a way that allowed them to be accepted into the public sphere. Women were called on to assist in the decision making process of individual cases, select issues for lobbying and consider proposed Parliamentary provisions. In its First Report in 1846, the Associate Institution for Improving and Enforcing the Laws for the Protection of Women, recorded that of its 904 subscribers, $193(21 \%)^{77}$ were women, and from the Rainer Archive the apparent dominance of women in many of the societies is striking. Women sat on the council of the ASPWC and were consulted and involved in casework issues. In fact female 
members were actively sought out, when the Society became an Associated Society in 1878 the Chair, the Marquis of Townsend, invited five ladies involved in charitable works to set up a ladies committee sub-joined to the main committee ${ }^{78}$.

Modern critics however, have tended to downplay the effectiveness of these societies. Ronald Pearsall has argued that cases of child sexual abuse were so rare as to receive substantial newspaper coverage ${ }^{79}$ but it is becoming evident that in fact it was not just the sensationalized cases that were reported. Recent research by Judith Rowbotham, examining newspaper reports of summary trials on a day-by-day basis, reveal that many cases of sexual assaults on children were not only heard at this level but appear on a regular basis in the daily newspaper digests of the police courts. Because there was a willingness to dispose of such cases as quickly and quietly as possible, even at assize levels, such cases are often less overtly apparent than the more sensationalized ones, but exist nonetheless ${ }^{80}$. Pearsall also asserts that, "Children had no-one to take their problems to. There were a number of protection societies, especially in London, but they were fragmented, ill-organised and anonymous. Few had heard of them, least of all children ${ }^{81}$. George Behlmer is also highly dismissive of the Society for the Protection of Women and Children describing it as «misnamed» in that he accuses it of preferring cases of physical assault committed against wives rather than sponsoring cases of sexual assault committed against children ${ }^{82}$. It is easy to be pessimistic but despite nineteenth century understandings about child sexual abuse and the limitations of the law, the evidence both from the press and the Rainer Foundation Archive indicate a more positive note. Many children were caught by the safety net provided by these societies. In particular, the ASPWC was involved in a significant number of cases where very young children were abused by members of their own family. The first page of the inaugural Minute Books for the Associated Society in 1878 starts with a note of concern about the tender age of many of the victims of indecent and criminal assault (defilement) which the society had dealt with in the previous year - some 50 under the age of 13 years. Despite the fact it was noted that many were too young to give evidence against their aggressors the minutes record that a number of convictions were successfully obtained with sentences of a few months to 2 years, all with hard labour. In addition the Society records that «the crime of rape is frequently committed upon young girls, some of whom were ten, nine or even eight years of age. The sentences passed... ranged from nine to twelve months, ten years and penal servitude for life» ${ }^{83}$. Without the intervention of this society many of these cases would never have been prosecuted.

Maeve Doggett too has argued that the Society for the Protection of Women and Children was ineffective, limited by obscurity and lack of funding ${ }^{84}$. Certainly the Society, as most modern charities today, was constantly seeking out funding and there is evidence of possible financial irregularities as, in 1879, a sub-committee was set up to "enter into a full and complete investigation of the monetary condition,» largely over the issue of expenses claims for some of its full time officers ${ }^{85}$. But surely the fact that the Society initiated numerous prosecutions against not only male perpetrators but also mothers and female child carers for the ill-treatment of children in their care through its "active instrumentality» should not be diminished ${ }^{86}$ ? The SPWC dealt with some 1,006 cases in 1876-1877, and as an Associated Society in 1879 it received over 2,250 consultations and 634 cases while its prosecuting officer conducted 222 enquiries and made 109 attendances at the police courts. Many of these applications sought 
advice only but they covered a wide range of crimes and other legal and domestic issues ${ }^{87}$. In 1880 there was a further increase in the Society's workload. At the Annual Meeting in January 1880 it was reported that there had been a large increase in the number of cases accepted. Mr Stuart, the prosecuting officer, had dealt with 449 enquiries and made 164 attendances at the police courts and sessions houses the previous year. The Society had also secured prison sentences of seven years penal servitude or more in 38 cases emphasizing the seriousness of the crimes with which it was involved ${ }^{88}$. Not only did the Society actively publicise the problem of domestic violence, it also provided assistance and sought legal redress on behalf of women and children victimized by sexual violence. Even if the Society only sponsored a relatively small number of cases, and as yet we do not have the evidence to determine this one way or the other until the final cataloguing of the Rainer archive is complete, initial impressions suggest that their impact was significant. And for those individual women and children personally affected the fact that somebody was prepared and willing to support them in a mainly unforgiving and masculine legal environment should not be underestimated. Similarly the existence and availability of an agency proffering free advice and information for women, parents and guardians should not be overlooked or undermined. Arguably even today, when there is greater sensitivity and understanding towards victims of sexual violence and women are more empowered, victim support schemes, rape crisis organizations and other support bodies may not realistically be able to achieve that much more within the confines of the legal system, but in respect of the individual victims concerned would we be so disparaging?

\section{Conclusion}

21 Victorian societies such as the ASPWC and others fulfilled a key role in addressing and dealing with incidents of sexual violence perpetrated against both women and children, a role partly determined and created by themselves and partly indirectly forced upon them because of the prevailing limitations and inequities of the law and the legal process. Whereas eighteenth century societies had focused on a more communal and morally reformative approach to maintain societal order, these nineteenth century societies adopted a more individualistic stance and were more concerned with the delivery of individual justice. Their activities in undertaking prosecutions and engaging in mediation on an individual basis, together with their willingness to forge campaigns to reform the law and force the legal system to acknowledge their role and existence, mark these societies out in a very different light to their eighteenth century forebears. Without an official prosecutory agency, such as the modern Crown Prosecution Service, many defendants would have escaped trial and many cases of sexual assault would never have been reported or recorded but for the involvement of these societies. The fact that they were largely independent and not state controlled enhanced their credibility and enabled them to operate at all levels. As Wiener has pointed out ${ }^{89}$, the (predominantly male) public were often slow to acknowledge the existence and impact of such crimes. These societies led the way and contributed, in very real terms, to the criminalization of sexual violence and those who perpetrated it during the Victorian period. After all the epitome of a dysfunctional society is one where there are too many obvious victims of injustice, especially women and children. The Victorian age was not one that, philosophically, relied heavily on prescriptive legislation, unlike today; rather it preferred a more permissive approach. However, with the inexorable increase in 
statute law and despite the rhetoric, these societies operated as a conduit through which the laissez-faire doctrine could be manipulated to achieve compromises within an increasingly prescriptive legal environment. They thrived because of the interest of substantial numbers of women as well as high profile men. Each had its own agenda but in endeavouring to secure their own objectives these societies indirectly facilitated access to the law, and not only attempted to secure justice for many ordinary women and children but sent a clear message to society that sexual violence was no longer acceptable or justifiable.

\section{BIBLIOGRAPHY}

Andrew, D., Philanthropy and Police, London Charity in the Eighteenth Century, Princeton, Princeton University Press, 1989.

Bartley, P., Preventing Prostitution: the Ladies' Association for the Care and Protection of Young Girls in Birmingham, 1887-1914, Women's History Review, 1998, 37-58.

Behlmer, G., Child Abuse and Moral Reform in England 1870-1908, Stanford, University Press, 1982.

Bentley, D., English Criminal Justice in the Nineteenth Century, London, Hambledon Press, 1998.

Bloch, I., A History of English Sexual Morals: Sexual Life in England Past and Present, London, Arco Publications, 1958.

Bristow, E. J., Vice and Vigilance, Purity Movements in Britain since 1700, Dublin, Gill \& Macmillan, 1977.

Clark, A., Women's Silence, Men's Violence: Sexual Assault in England 1770-1845, London, Pandora, 1987.

Conley, C., The Unwritten Law: Criminal Justice in Victorian Kent, Oxford University Press, 1991.

D'Cruze, S., Crimes of Outrage, Sex, Violence and Victorian Working Women, London, UCL Press, 1998, 89-103.

Davis, J., Prosecutions and their Context in Hay, D., Snyder, F., Policing and Prosecution in Britain 1750-1850, Oxford, Clarendon Press, 1989, 343-395.

Doggett, M. E., Marriage, Wife Beating and the Law in Victorian England, University of South Carolina Press, 1993.

Emsley, C., Crime and Society in England, 1750-1900, Harlow, Longman, 1996, (2 ${ }^{\text {nd }}$ ed.).

Hay, D., Prosecution and Power in Hay, D., Snyder, F., Policing and Prosecution in Britain 1750-1850, Oxford, Clarendon Press, 1989.

Hitchcock, T., English Sexualities, 1700-1800, Basingstoke, Macmillan, 1997.

Jackson, L., Child Sexual Abuse in Victorian England, London, Routledge, 2000.

Knelman, J., Twisting in the Wind: The Murderess and the English Press, Toronto, University of Toronto Press, 1998.

Mason, M., The Making of Victorian Sexual Attitudes, Oxford, Oxford University Press, 1995. 
Meldrum, T., London Domestic Servant's Evidence 1660-1750: Servant-employer Sexuality in the Patriarchal Household, in Hitchcock, T., King, P., Sharpe, P., Chronicling Poverty: the Voice and Strategies of the English Poor, 1640-1840, Basingstoke, Macmillan, 1997, 47-69.

Pearsall, R., Sexual Abuse in Victorian Britain, The Criminologist, 1995, 19, 155-161.

Philips, D., Good Men to Associate and Bad Men to Conspire in Hay, D., Snyder, F., Policing and Prosecution in Britain 1750-1850, Oxford, Clarendon Press, 1989, 113-170.

Platt, A. M., The Child Savers: The Invention of Delinquency, Chicago, University of Chicago Press, $1969,\left(2^{\text {nd }}\right.$ ed.).

Prochaska, F., Women and Philanthropy in Nineteenth Century England, Oxford, Clarendon Press, 1980.

Prochaska, F., The Voluntary Impulse: Philanthropy in Modern Britain, London, Faber, 1988.

Rowbotham, J., Stevenson, K., Causing a Sensation: Media and Legal Representations of Bad Behaviour in same eds., Behaving Badly: Social Panic and Moral Outrage - Victorian and Modern Parallels, Aldershot, Ashgate, 2003.

Smith, J., Rochester, C., Hedley, R., An Introduction to the Voluntary Sector, London, Routledge, 1995. Stevenson, K., Unequivocal Victims: The Historical Mystification of the Female Complainant in Rape Cases, Feminist Legal Studies, 8, 2000a, 346-366.

Stevenson, K., Ingenuities of the Female Mind: legal and public perceptions of sexual violence in Victorian England 1850-1950, in D'Cruze, (ed.,) Everyday Violence in Britain 1850-1950, Harlow, Longmans, 2000b, 89-103.

Styles, J., Print and Policing, in Hay, D., Snyder, F., Policing and Prosecution in Britain 1750-1850, Oxford, Clarendon Press, 1989, 55-111.

Taylor, D., Crime, Policing and Punishment in England 1750-1914, Basingstoke, Macmillan, 1998.

Terrot, C., The Maiden Tribute: A Study of the White Slave Traffic of the Nineteenth Century, London, Frederick Muller, 1959.

Walkowitz, J., City of Dreadful Delight Chicago, University of Chicago Press, 1992.

Wiener, M.J., The Victorian Criminalization of Men, in Spierenburg, P., Men and Violence, Gender, Honor and Rituals in Modern Europe and America, Columbia, Ohio State University Press, 1998, 197-212.

\section{NOTES}

3. For example see Mason (1995); Prochaska (1980); Bloch (1958).

4. In July $1885 \mathrm{~W}$ T Stead, editor of the Pall Mall Gazette, caused a sensation with his journalistic revelations based on the investigation by his Secret Commission of the 'white slave trade' and the decoying of young English women and girls to Belgium. Entitled 'The Maiden Tribute to Modern Babylon,' and published 6-10 July 1885, this was timed to secure the passage of the Criminal law Amendment Act 1885 being debated in Parliament and the repeal of the Contagious Diseases Acts. The scandal concerned a plan, executed with Josephine Butler's assistance, whereby a young virgin was used as a stooge and procured for $£ 5$ thus, according to Stead, proving the sale of, and trafficking in, young girls. See Terrot (1959); Walkowitz (1992).

5. See Judith Knelman's work on Florence Maybrick for example, Knelman (1998).

6. See Jackson (2000, ch. 3). 
7. Anna Clarke, for example, makes a passing reference to the role of the National Vigilance Campaign in providing solicitors to conduct prosecutions in cases of rape and other sexual assaults in the latter half of the nineteenth century, Clark (1987, p. 133).

8. Prochaska (1980, p. 28).

9. A project supported by the Economic and Social Research Council and managed by SOLON: Promoting Interdisciplinary Studies in Bad Behaviour and Socially Visible Crime. A database created from summarized extracts of a range of crime reports from Victorian newspapers from these years including The Times, Daily Telegraph, News of the World, Reynolds Weekly and Lloyds Weekly can be found at http://solon.ntu.ac.uk/home.htm.

10. This major archive held at the Galleries of Justice Museum of Law, Nottingham holds a complete run of the society's Minute Books from 1878-1938 and annual reports from 1890-1934 (reference Rainer Foundation Archive, NOTML, L48, Minute Books 1878-1914). As their contents are still in the process of being catalogued most references in this paper are to the Minute Books 1878-1879. The wealth of information for these two years alone, however, indicate just how influential and active this organization was. The author acknowledges, with gratitude, the help and assistance of the Museum of Law, particularly the Archivist, Bev Baker and Nottingham Trent University funded Cataloguer, Shani Cassidy.

11. Also under Charities Law if a charity becomes financially unsustainable it does not cease to exist and may be subsumed within another organization often at the suggestion of the Charities Commission.

12. The Associate Institute for the Protection of Females was involved in sponsoring a number of Bills through Parliament to prevent organized prostitution, which were largely dismissed by the House of Lords in 1844 and 1847. In 1848 Samuel Wilberforce had more success in securing the passage of the Protection of Females Bill, which became the Protection of Females Act 1849.

13. Based at 85 Strand, London.

14. Epitomized by the Society for the Suppression of Vice and Encouragement of Religion and Virtue - the 'Vice Society,' founded in 1802 by several leading Evangelicals including Lord Wilberforce. Its aim was to stamp out all forms of vice and immorality, primarily through the closure of brothels and destruction of 'obscene' material irrespective of artistic or aesthetic merit. In 1804 it merged with the Proclamation Society which remained its parent body. It survived until the 1880s but largely collapsed after providing financial assistance to the newly founded National Vigilance Association in 1885. The Society secured the enactment of the Obscene Publications Act 1857 and while its primary target was sexual morality it also instigated proceedings against Sabbath breaking, cruelty to animals, weights and measures frauds, lotteries, adultery and seduction. An American Society for the Suppression of Vice was founded in New York by Anthony Comstock in 1873 for the suppression of obscene material and gambling. See also Mason (1995, ch. 2).

15. Hitchcock (1997, p. 102).

16. Andrew (1989, p. 201).

17. See Andrew (1989, ch. 6).

18. Hitchcock (1997, ch. 7).

19. See Emsley (1996, ch. 8).

20. See Davis (1989, p. 399); Bentley (1998, pp. 7-8).

21. Associations advertised their services in newspapers and on occasion supported nonmembers without means see See Styles (1989, pp. 62-63); Philips (1989, pp. 138-139).

22. Taylor (1998, p. 110).

23. See Emsley (1996, pp. 198-207).

24. See Philips (1989).

25. See Bentley (1999, p. 19).

26. For example, Benet's Act 1818, Criminal Justice Act 1826. 
27. First of the three Jervis Acts 1848, Criminal Justice Act 1855. See Taylor (1998, ch. 6).

28. See Styles (1989, pp. 62-63); Philips (1989, pp. 138-139).

29. See Meldrum (1997).

30. See D'Cruze (1998); Clark (1987).

31. See Wiener (1998, p. 203); Hay (1989, p. 377).

32. Conley (1991, p. 91).

33. Ibid. p. 95.

34. See Emsley (1996, p.161); Conley (1991, p. 92).

35. See Smith et al. (1995, pp. 19-21).

36. Prochaska (1988, p. 223).

37. Ibid. (p. 23).

38. Wiener (1998, pp. 200-201).

39. An early example is the London Society for the Protection of Young Females and Prevention of Juvenile Prostitutes founded 1835. See Bartley (1998, pp. 37-58); Platt (1969).

40. For example, the Society for the Protection of Young Women lobbied for the Protection of Females Act 1849; the National Vigilance Society did the same with respect to the Criminal Law Amendment Act 1885.

41. Jackson (2000), and see Behlmer (1982).

42. Jackson (2000, pp. 59-61).

43. Hyams was sentenced to 10 months hard labour. The Times, 16 June 1856.

44. Bristow (1977, p. 61).

45. The Times, 11 March 1852.

46. The Times, 8 January 1857. The work of the Institute appears to have found favour with the Duke of Norfolk as The Times makes a one-line reference that he donated $£ 100$ in 1857 . The Times, 4 June 1857.

47. The Times, 18 June 1858. The downgrading of sexual assaults in this way was a common practice, see Stevenson (2000a); Conley (1991 pp. 81-86).

48. The Times, 2 March 1858.

49. The Times, 17 August 1858.

50. The Times, 18 February 1858.

51. See Stevenson (2000b).

52. Daily Telegraph, 15 March 1870.

53. The Society's Annual Report for 16 June 1879 notes that «Mr Caldwell (solicitor) has given advice in both criminal and civil cases». Rainer Foundation Archive, NOTML, L48, Minute Books 1878-1914.

54. Rainer Foundation Archive, NOTML, L48, Minute Books 1878-1914. These payments were often noted on the balance sheet as «cash received on trust».

55. D'Cruze cites a similar example of a repeat sex offender called «Owd Stiff» where the local Middleton community enjoined to ensure his appearance at court in 1863 after a number of women made complaints about his predilection to expose himself to young girls in the area. D'Cruze (1998, p. 119).

56. Rainer Foundation Archive, NOTML, L48, Minute Books 1878-1914.

57. Ibid.

58. See Jackson (2000, pp. 59-61) for more discussion of the work of this particular society.

59. Reynolds Weekly, 21 April 1861.

60. Rainer Foundation Archive, NOTML, L48, Minute Books 1878-1914.

61. Daily Telegraph, 6 July 1870.

62. Daily Telegraph, 8 August 1870. 
63. For example, William Shaen acted as solicitor for the Associate Institute for the Protection of Women and Children and Frederick George Cordwell was solicitor for the Society for the Protection of Women and Children.

64. Rainer Foundation Archive, NOTML, L48, Minute Books 1878-1914, case 263.

65. Rainer Foundation Archive, NOTML, L48, Minute Books 1878-1914.

66. Though given that this was essentially an advisory position for the first 30 years it is unclear whether cases were taken over or guidance simply given. See Emsley (1996, p. 190). Unfortunately the Minute Books are silent in this respect.

67. Pall Mall Gazette, 4 March 1865.

68. Conley also notes that the Tonbridge Telegraph, 4 March 1865, details the fine as $£ 1$ and not £5 (1991, p. 87, fn.59). To resolve this discrepancy would require reference to the original court records which may not have survived. The Pall Mall Gazette, however, under the editorship of Sir James Fitzjames Stephen, did enjoy a good reputation for its accuracy at the time. See Rowbotham, Stevenson (2003).

69. Rainer Foundation Archive, NOTML, L48, Minute Books 1878-1914, case 521.

70. The Times, 6 January 1859.

71. Founded in 1885 by Josephine Butler (who also founded the Personal Rights Association in 1871 and Social Purity Alliance in 1873) and subsumed not only the Vice Society which provided it with funds during the $1880 \mathrm{~s}$, but also the Central Vigilance Society and the Travellers Aid Society.

72. «The Sentinel»: the Journal of the Association for the Improvement of Public Morals, 18 October 1880.

73. Daily Chronicle and Clerkenwell News, 10 April 1872.

74. Prochaska (1980, p. 37).

75. Taylor (1998, p. 110).

76. Louisa Hubbard, The Englishwoman's Yearbook 1893 as cited in Prochaska (1980, p. 224).

77. Prochaska (1980, p. 236).

78. Rainer Foundation Archive, NOTML, L48, Minute Books 1878-1914.

79. Pearsall (1995).

80. For examples of Rowbotham's summaries see the SOLON database http://solon.ntu.ac.uk/ home.htm.

81. Pearsall (1995, p. 160).

82. Behlmer (1982, p. 59) and see Jackson (2000, p. 61) who is also critical of Behlmer's approach.

83. Rainer Foundation Archive, NOTML, L48, Minute Books 1878-1914.

84. Doggett (1993, p.111).

85. Rainer Foundation Archive, NOTML, L48, Minute Books 1878-1914.

86. Ibid.

87. See also report in «The Sentinel», No.4 1880 p. 7.

88. Rainer Foundation Archive, NOTML, L48, Minute Books 1878-1914.

89. Wiener (1998, p. 205). 


\section{ABSTRACTS}

Victorian female victims of sexual violence often found themselves isolated within the criminal justice system. No state agency existed to initiate prosecutions for rape or indecent assault thus the victim or her family had to commence formal proceedings themselves. Drawing on nineteenth century newspaper reports and records from the Rainer Foundation Archive this paper argues that numbers of female victims benefited from the support offered by certain very active voluntary societies in prosecuting such cases. From disesteemed beginnings, caseloads increased exponentially as the century progressed and society became more willing both to accept the fact of sexual violence and its criminalization. The existence and operation of these societies made a very real impact within the criminal justice process and publicly signalling that masculine sexual violence was no longer justifiable.

Les femmes victimes de violences sexuelles à l'époque victorienne étaient souvent isolées face à la justice pénale. Il n'existait pas d'institution étatique susceptible d'engager les poursuites pour viol ou attentat à la pudeur et la victime, ou sa famille, devait, par conséquent, déclencher l'action pénale. Le présent article s'appuie sur la presse de l'époque et sur les archives de la Rainer Foundation pour défendre l'idée selon laquelle de nombreuses victimes purent s'appuyer dans cette action sur certaines associations de défense très actives. Peu nombreuses au début du $\mathrm{XIX}^{\mathrm{e}}$ siècle, les affaires se multiplièrent de façon exponentielle à mesure qu'on avançait dans le siècle et que la société était davantage disposée à admettre le fait qu'il existait des violences sexuelles et qu'il fallait les criminaliser. L'existence et les interventions de ces associations eurent un impact très réel sur le fonctionnement du système pénal et manifestaient publiquement le fait que la violence sexuelle masculine n'était plus justifiable.

\section{AUTHOR}

\section{KIM STEVENSON}

Senior Lecturer in Law, Department of Academic Legal Studies, Nottingham Trent University, Burton Street, Nottingham, NG1 4BU, kim.stevenson@ntu.ac.uk

Dr Kim Stevenson is a senior lecturer in law in the Department of Academic Legal Studies. She lectures in Constitutional and Administrative Law and Sexuality and the Law. Research interests include crime history, sexual offences, sexuality and violence. She is currently working on a number of projects including the relationship between the judiciary and the press media in both Victorian and the late twentieth century; sexual violence in the nineteenth century and is jointly editing a compilation of essays entitled Criminal Conversations: Victorian Crimes, Social Panic and Moral Outrage. Previous publications: Behaving Badly: Visible Crime, Social Panics and Legal Responses Victorian and Modern Parallels, (joint editor with Judith Rowbotham) (Aldershot, Ashgate, 2003); Unequivocal Victims: the Development of the Historical Mystification of the Female Complainant in Rape Cases (2000) Feminist Legal Studies 8/3 343-66; «Ingenuities of the Female Mind: Legal and Public Perceptions of Sexual Violence in Victorian England 1850-1890» in Shani D'Cruz (ed.) Unguarded Passions: Gender, Class and Everyday Violence in Britain c.1850-c1950, (2000, Longmans, 89-103). 